University of Nebraska - Lincoln

DigitalCommons@University of Nebraska - Lincoln

USDA National Wildlife Research Center - Staff Publications
U.S. Department of Agriculture: Animal and Plant Health Inspection Service

2020

\title{
Additive and non-additive responses of seedlings to simulated herbivory and drought
}

\author{
Kasey Barton \\ University of Hawai'i at Mānoa, kbarton@hawaii.edu
}

Aaron B. Shiels

USDA, APHIS, Wildlife Services, aaron.b.shiels@aphis.usda.gov

Follow this and additional works at: https://digitalcommons.unl.edu/icwdm_usdanwrc

Part of the Natural Resources and Conservation Commons, Natural Resources Management and Policy Commons, Other Environmental Sciences Commons, Other Veterinary Medicine Commons, Population Biology Commons, Terrestrial and Aquatic Ecology Commons, Veterinary Infectious Diseases Commons, Veterinary Microbiology and Immunobiology Commons, Veterinary Preventive Medicine, Epidemiology, and Public Health Commons, and the Zoology Commons

Barton, Kasey and Shiels, Aaron B., "Additive and non-additive responses of seedlings to simulated herbivory and drought" (2020). USDA National Wildlife Research Center - Staff Publications. 2374. https://digitalcommons.unl.edu/icwdm_usdanwrc/2374

This Article is brought to you for free and open access by the U.S. Department of Agriculture: Animal and Plant Health Inspection Service at DigitalCommons@University of Nebraska - Lincoln. It has been accepted for inclusion in USDA National Wildlife Research Center - Staff Publications by an authorized administrator of DigitalCommons@University of Nebraska - Lincoln. 


\title{
Additive and non-additive responses of seedlings to simulated herbivory and drought
}

\author{
Kasey E. Barton ${ }^{1}$ (D) | Aaron B. Shiels ${ }^{2}$
}

${ }^{1}$ School of Life Sciences, University of Hawai'i at Mānoa, Honolulu, Hawaii

${ }^{2}$ USDA, National Wildlife Research Center, Fort Collins, Colorado

\section{Correspondence}

Kasey E. Barton, School of Life Sciences, University of Hawai'i at Mānoa, 3190 Maile Way, Room 101, Honolulu, HI 96822, USA.

Email: kbarton@hawaii.edu

Funding information

USDA APHIS Wildlife Research Program

Associate Editor: Jennifer Powers

Handling Editor: James Dalling

\begin{abstract}
Drought is a global threat, increasing in severity and frequency throughout tropical ecosystems. Although plants often face drought in conjunction with biotic stressors, such as herbivory or disease, experimental studies infrequently test the simultaneous effects of drought and biotic stress. Because multiple simultaneous stressors may have non-additive and complex effects on plant performance, it is difficult to predict plant responses to multiple threats from research examining one stress at a time. Using an experimental approach in the greenhouse, we investigated potential nonadditivity in seedling growth and survival to simulated drought and herbivory across a phylogenetically diverse pool of ten Hawaiian plant species. Overall, seedlings showed limited tolerance, defined as similar growth and survival in stressed compared with control (non-stressed) plants, to simulated herbivory and drought, with the combined effects of both stressors to be generally additive and negative across species. Significant variation in stress tolerance was detected among species, and species variation was explained, at least in part, by functional traits such that species with larger root/shoot ratios and smaller seeds, tended to demonstrate greater herbivory and drought tolerance. Future research incorporating additional trait analysis and different stressors could shed light on mechanisms underlying seedling stress tolerance and clarify whether additivity, as detected in this study, extends across other combinations of stressors. Such work will provide needed insights into the regeneration of seedlings in tropical forests under threats of herbivory and climate change.
\end{abstract}

\section{KEYWORDS}

compensatory growth, drought tolerance, Hawaiian Islands, herbivory tolerance, interactive effects, press drought, pulse drought

\section{1 | INTRODUCTION}

Drought is increasing globally (IPCC 2014) and is one of the greatest climate change threats to both seasonal and aseasonal tropical ecosystems (Allen et al., 2017; Bonal, Burban, Stahl, Wagner, \& Herault, 2016; McDowell et al., 2018; Schwalm et al., 2017). In addition to the direct effects of drought suppressing plant growth and survival, there can be strong indirect effects due to increased pest and pathogen damage (Anderegg et al., 2015). Indirect effects often result in non-additivity between multiple stressors such that plants experiencing drought and herbivory simultaneously have lower performance than the summed effects of each stressor alone (Davidson, Gottschalk, \& Johnson, 1999; Denton, Smith, Hamerlynck, \& Sheley, 2018; Wallin \& Raffa, 2001). Non-additive effects between 
drought and herbivory may occur due to signaling cross talk underlying plant responses to multiple stressors (Atkinson \& Urwin, 2012), or because drought alters the likelihood or intensity of herbivory on plants. In general, non-additive effects emerging from interactions among genotypes within species (Barton et al., 2015) and among species within communities (Ball, Hunter, Kominoski, Swan, \& Bradford, 2008; Bernardo, Goad, Vitt, \& Knight, 2019; Thompson, MacLennan, \& Vinebrooke, 2018) are increasingly recognized to play important roles in community dynamics and environmental stress tolerance in plants and warrant further examination in tropical systems.

There is considerable evidence that drought-stressed plants have weakened resistance to herbivores, which could magnify the effects of herbivory on plants experiencing drought and lead to non-additivity between these combined stressors on plant performance. For example, secondary chemicals that deter herbivores may decline in production under drought, thereby making plants more attractive to herbivores (Gaylord et al., 2013; Mundim \& Pringle, 2018; Netherer et al., 2015). Drought is also linked to insect outbreaks, due to the combined effects of drought-weakened tree resistance and direct effects on insect population dynamics (Anderegg et al., 2015; Raffa et al., 2008), although drought-induced insect outbreaks may be less common in tropical than temperate forests (Anderegg et al., 2015; Dyer, Carson, \& Leigh, 2012). In addition to resistance traits that deter herbivores, plant defenses also include post-damage induced responses contributing to compensatory growth and recovery as part of herbivory tolerance (Fornoni, 2011; Strauss \& Agrawal, 1999). How drought influences plant tolerance to herbivory remains poorly studied (Jamieson, Trowbridge, Raffa, \& Lindroth, 2012), particularly in tropical plants, despite the prevalence of these simultaneous stressors in tropical forests.

Plant tolerance to herbivory is defined as the maintenance of fitness in damaged compared with undamaged control plants (Fornoni, 2011). Plants tolerate herbivory through increases in photosynthesis (Fang, Yuan, Wang, \& Zhao, 2006; Thomson, Cunningham, Ball, \& Nicotra, 2003), mobilization of stored reserves (Bossdorf, Schroder, Prati, \& Auge, 2004; Latzel, Malikova, \& Klimesova, 2011), and phenological shifts leading to early reproduction (Freeman, Brody, \& Neefus, 2003). Herbivory tolerance at the seedling stage has been shown to increase with high light efficiency in photosynthesis (Barton, 2016) and from investment in storage tissues, such as cotyledons and roots (Armstrong \& Westoby, 1993; Barton, 2013; Lurie, Barton, \& Daehler, 2017). Herbivory tolerance is likely to be influenced by drought due to shared hormone signaling networks and underlying mechanistic traits. The two primary hormones mediating stress responses to drought and herbivory are abscisic acid and jasmonic acid, which are themselves involved in a positive feedback mechanism that results in "priming" of plants to respond more efficiently to subsequent episodes of stress (Avramova, 2019; Nguyen, Rieu, Mariani, \& van Dam, 2016). Although this shared signaling network suggests that drought-stressed plants should have elevated induced defense (i.e., tolerance) following herbivory (Avramova, 2019), the dependence of both drought and herbivory tolerance on non-structural carbohydrates and conflicting biomass allocation plasticity can lead to negative non-additivity. For example, non-structural carbohydrates function to maintain osmoregulation, thereby facilitating water uptake by roots under drought stress (O'Brien, Leuzinger, Philipson, Tay, \& Hector, 2014), but in contrast, are quickly mobilized to shoot meristems to facilitate compensatory growth for herbivory tolerance (Myers \& Kitajima, 2007; Willaume \& Pages, 2011). Thus, drought-stressed plants are likely to be constrained in their capacity to mobilize non-structural carbohydrates aboveground for herbivory tolerance without compromising drought tolerance. Similarly, biomass allocation is typically very plastic in response to both drought and herbivory, although in different patterns. Drought-stressed plants typically prioritize growth belowground (Denton et al., 2018; Larson \& Funk, 2016; Lucas, Bruna, \& Nascimento, 2013), while herbivory-stressed plants typically prioritize growth aboveground, at least in response to aboveground herbivory (Barton, 2016; Stevens, Kruger, \& Lindroth, 2008; Yoshizuka $\&$ Roach, 2011). Related storage and life-history traits, such as seed size and relative growth rate, have also been implicated in stress tolerance to both drought and herbivory (Gianoli \& Salgado-Luarte, 2017; Green \& Juniper, 2004; Krishnan, Barua, \& Sankaran, 2019; SalgadoLuarte \& Gianoli, 2017), highlighting the overlap in biotic and abiotic stress tolerance mechanisms. Non-additivity between drought and herbivory tolerance is therefore likely, although much less well-studied than that of drought and herbivory resistance, particularly for tropical plants.

At the population scale, plant resilience to combined drought and herbivory will depend on population dynamics and demographic processes. In particular, the migration of populations to track suitable climate, replacement of dying canopy trees, and in situ evolution to changing climate will all depend on successful seedling recruitment (Christmas, Breed, \& Lowe, 2016; Maron, Baer, \& Angert, 2014; Martinez-Vilalta \& Lloret, 2016). In general, drought and herbivory are common sources of seedling mortality (Moles \& Westoby, 2004) and play key roles in determining recruitment patterns and species distributions in the tropics (Baltzer \& Davies, 2012; Gaviria, Turner, \& Engelbrecht, 2017; Weissflog, Markesteijn, Lewis, Comita, \& Engelbrecht, 2018). Because seedlings tend to be quite vulnerable to drought due to their limited carbohydrate reserves, shallow roots, and underdeveloped woody tissue (Comita \& Engelbrecht, 2014; Gerhardt, 1996; Marod, Kutintara, Tanaka, \& Nakashizuka, 2002), the regeneration niche may be more narrow with regard to aridity than that of the mature trees. In addition, herbivory tolerance is generally weaker in seedlings than older ontogenetic stages (Massad, 2013). Thus, investigating potential non-additivity in tolerance to herbivory and drought is particularly important at the seedling stage and could determine patterns of recruitment and species assemblages under climate change.

We tested seedling tolerance to combined herbivory and drought using an experimental approach on a diverse assemblage of Hawaiian plant species. Tropical islands, including the Hawaiian Islands, are biodiversity hot spots, with high rates of endemism (Kier et al., 2009). Tropical island floras are also among the most threatened globally, 
TAB LE 1 Species descriptions of 10 taxa included in the experiment. Seed mass (grams) data were obtained from populations used in the experiments (mean $n=20$ ), with the exception of Metrosideros polymorpha, for which data were obtained from previous research

\begin{tabular}{llllll} 
Species & Family & Distribution & Habitat & Growth form & Seed mass (G) \\
\hline Eragrostis grandis & Poaceae & Endemic & Mesic, wet forest & Grass & 0.00015 \\
Argemone glauca & Papaveraceae & Endemic & Shrubland, coastal & Herb & 0.00288 \\
\hline Bidens torta & Asteraceae & Endemic & Dry, mesic, wet forest & Herb & 0.00141 \\
Jacquemontia sandwicensis & Convolvulaceae & Endemic & Coastal & Prostrate Herb & 0.00357 \\
\hline Dodonaea viscosa & Sapindaceae & Indigenous & Shrublands, dry forest & Shrub & 0.00474 \\
Acacia koa & Fabaceae & Endemic & Dry, mesic forest & Tree & 0.1133 \\
Metrosideros polymorpha & Myrtaceae & Endemic & Dry, mesic, wet forest & Tree & 0.000057 (Drake, 1992) \\
\hline Myrsine lessertiana & Primulaceae & Endemic & Mesic, wet forest & Tree & 0.05313 \\
\hline Nestegis sandwicensis & Oleaceae & Endemic & Dry, mesic forest & Tree & 0.4140 \\
Sophora chrysophylla & Fabaceae & Endemic & Dry forest, alpine & Tree & 0.06695 \\
\hline
\end{tabular}

with climate change and herbivory by invasive animals identified as key sources of native plant declines (Caujape-Castells et al., 2010; Harter et al., 2015). Drought is projected to increase in frequency and duration on the Hawaiian Islands, and, with simultaneous increases in temperatures, is leading to significantly greater water stress for Hawaiian plants (Chu, Chen, \& Schroeder, 2010; Cook, Smerdon, Seager, \& Coats, 2014; Frazier \& Giambelluca, 2017; Timm, Giambelluca, \& Diaz, 2015). Introduced mammals reduce Hawaiian seedling recruitment directly through consumption of flowers, seeds, and seedlings (Pender, Shiels, Bialic-Murphy, \& Mosher, 2013; Shiels \& Drake, 2011; Shiels, Pitt, Sugihara, \& Witmer, 2014), as well as indirectly through disturbance to the plant-growth substrate (Cole, Litton, Koontz, \& Loh, 2012; Murphy, Inman-Narahari, Ostertag, \& Litton, 2014). Non-native insects may similarly threaten seedling recruitment indirectly through damage to flowers or through failure to pollinate native plants (Aslan, Shiels, Haines, \& Liang, 2019; Aslan, Zavaleta, Tershy, Croll, \& Robichaux, 2014). Invasive slugs and snails also target native seedlings directly for consumption in Hawaiian forests (Joe \& Daehler, 2008; Shiels, Ennis, \& Shiels, 2014). While it has been predicted that island plants have weaker anti-herbivore defenses than continental plants due to the disharmonic herbivore communities on islands and the absence of some native herbivore guilds (Bowen \& VanVuren, 1997; Ziegler, 2002), comparative research on Hawaiian native versus non-native plant defenses and herbivory levels has been inconclusive (Funk \& Throop, 2010; Hoan, Ormond, \& Barton, 2014; Peñuelas et al., 2010; Sardans, Llusia, Niinemets, Owen, \& Peñuelas, 2010). Considering the extinction of a highly diverse native bird community consisting of many grazing species, it is likely that the native Hawaiian flora evolved under reasonably high herbivore pressure (Baldwin, 1947; Black, Hunter, Woog, Marshall, \& Bowler, 1998; Givnish, Sytsma, Smith, \& Hahn, 1994; Hess, Banko, Miller, \& Laniawe, 2014).

We quantified Hawaiian seedling tolerance to simulated drought and herbivory within a controlled experimental context in order to assess fitness consequences of consistent levels of damage and drought applied across a diverse species pool. Because seedling establishment depends on survival and growth, we consider these to be key fitness metrics for seedling stress tolerance (Barton \& Hanley, 2013). Herbivory was simulated through the mechanical removal of shoot biomass, in addition to an exogenous jasmonate application to further ensure that the full induced defense response was stimulated, providing a measure of the capacity for these species to tolerate herbivory at the seedling stage. While artificial damage does not reflect the likelihood of natural herbivory, by achieving consistent damage across species, it provides the most unbiased measure of herbivory tolerance (Tiffin \& Inouye, 2000). Our goal was to assess patterns within species as well as compare responses across species in order to begin to develop a general framework for seedling stress tolerance in the Hawaiian flora. Specifically, we examined the following predictions:

(i)There will be non-additivity between the effects of drought and herbivory on seedling survival and growth, detected as significant statistical interactions due to greater effects of combined herbivory and drought on seedling survival and growth than what would be expected based on summed seedling responses to the individual stress treatments.

(ii) Seedling tolerance to drought and herbivory will vary among species, and be positively linked to storage tissues, including root/shoot ratio and seed size.

\section{2 | METHODS}

To test for potential non-additive effects of simulated herbivory and drought on seedling performance, a greenhouse experiment was conducted at the Pope Greenhouses on the University of Hawaii at Manoa campus. Ten native species, wide-ranging in life forms and phylogenetic diversity (Table 1), were grown from seeds collected from at least 10 maternal plants in natural populations within 12 months of the experiment. Focal species include a grass (Eragrostis grandis), three herbaceous species from different habitat types (Argemone glauca, Bidens torta, and Jacquemontia sandwicensis), 
a widespread shrub (Dodonaea viscosa), Hawaii's most abundant and widespread canopy tree species (Acacia koa, Metrosideros polymorpha), and three other common tree species (Myrsine lessertiana, Nestegis sandwicensis, and Sophora chrysophylla). Seed mass was measured to the nearest $0.1 \mathrm{mg}$ for 20 individual seeds prior to germination to obtain species mean seed mass, except for M. polymorpha, which were too small to be detectable on our laboratory balances. For M. polymorpha, mean seed mass data were referenced from a previously published study (Drake, 1992). Seeds were germinated in the laboratory, following scarification or gibberellic acid application as needed to break dormancy, and were moved to the greenhouse as true leaves emerged. Due to space constraints and variation among species in their phenology, which influenced the timing of seed collections, species were not tested simultaneously, but were grown sequentially between June 2014 and April 2015. Because day length and temperature have very weak seasonality in Manoa where the greenhouses are located (Giambelluca et al., 2013), this rolling experimental design is unlikely to have introduced substantial abiotic variability to the experiments.

Seedlings were transplanted at the 1 or 2 true leaf stage into 1-gallon $(4.4 \mathrm{~L})$ pots filled with equal parts by volume Pro-Mix BX (65\%-75\% Canadian sphagnum peat moss, perlite, dolomitic and calcitic limestone, macro- and micronutrients, Glomus intraradices mycorrhizae inoculum) and black cinder, and treated with a single application of slow-release fertilizer (Osmocote (C). All seedlings were watered daily for one week to allow seedlings to recover from transplant shock. The full factorial experiment included 3 factors: drought, herbivory, and harvest time. Seedlings were randomly assigned to the treatment group at the time of transplant.

The drought factor includes three levels, including a control group watered daily to $100 \%$ field capacity ("100FC"), and two simulated drought treatments, to mimic a persistent decrease in precipitation ("70FC press drought"), or a period of no precipitation ("pulse drought"). These drought treatments simulate annual decreases in precipitation as well as more consecutive days without rainfall, both of which are predicted for the Hawaiian Islands (Frazier \& Giambelluca, 2017; Timm et al., 2015). The 70FC group received water three times a week to maintain the pots at $70 \%$ FC. At each watering event, 20 pots were randomly selected and weighed. The mean mass of these pots was compared with that of well-watered pots at $100 \% \mathrm{FC}$, and the amount of water necessary to bring them to $70 \%$ FC was measured and applied by hand to each pot (Sack, 2004). The 70FC drought treatment was applied throughout the experiment, starting one week after transplant For our soil media, the 100FC and 70FC treatments correspond to soil matric potentials of -2.6 and $-4.7 \mathrm{kPa}$, respectively, as determined with a soil-water characteristic curve following the Tempe pressure cell method (Westerband, Bialic-Murphy, Weisenberger, $\&$ Barton, 2020). Plants in the pulse-drought treatment received no water for a duration of up to 28 days. For species that wilted before 28 days, the pulse drought was ended as soon as $50 \%$ of the plants had severely wilted (Engelbrecht \& Kursar, 2003). At the end of the pulse drought, each pot was weighed so that gravimetric water content (\% FC) could be calculated. Following the end of the pulse drought, plants in this treatment group were watered daily throughout the rest of the experiment.

The herbivory factor included a damage treatment fully crossed with the drought treatment (applied to half of the plants in each of the three drought treatment groups). One week following the end of the pulse-drought treatment, herbivory was simulated by clipping the stem to remove $50 \%$ of leaves and the apical meristem, which approximates the herbivory by crabs, birds, mollusks, and rodents that these species most commonly experience at the seedling stage. Because our goal was to activate the induced responses underlying herbivory tolerance, which are known to be mediated by the jasmonate signal transduction pathway (Atkinson \& Urwin, 2012), we also treated damaged plants with an exogenous application of jasmonic acid by spraying the plants with a $0.5 \mathrm{mM}$ jasmonic acid solution until tissues were saturated and dripping (Rasmann, Johnson, \& Agrawal, 2009). Control plants were sprayed with distilled water at the same time.

For the harvest factor, plants were harvested at three different times, allowing us to investigate the immediate- and long-term effects of drought and herbivory on seedling performance. The first group ("pre-harvest") were harvested immediately prior to the herbivory treatments, one week following the end of the pulse drought. Half of the remaining plants were harvested two ("early harvest") and five ("late harvest") weeks after the herbivory treatment. Harvested plants were separated into shoots and roots, oven-dried at $60^{\circ} \mathrm{C}$ for 7 days, and weighed to the nearest $0.1 \mathrm{mg}$.

Tolerance was quantified on the basis of survival and growth (total biomass) in response to the drought and herbivory treatments. Biomass data were log-transformed as needed to meet assumptions of normality for analysis. Because species varied considerably in size, leading to heteroscedasticity, and because species trials were not run concurrently, we analyzed each species separately. For a few species, germination occurred over time, leading to temporal blocks, and for these species, block was included in the analyses as a random factor. All analyses were done using SAS for Windows 9.4, procedures "logistic," "mixed," and "reg."

Survival was analyzed using logistic regression with the main factors of drought and herbivory as well as their interaction. To investigate plasticity in root/shoot ratio in response to the drought treatments, data collected at the pre-harvest were analyzed in separate models with a single fixed effect of drought. Growth variables from the main experiment were analyzed with ANOVA models including the fixed factors drought (3 levels), herbivory (2 levels), and harvest time (2 levels), and block as a random factor (where appropriate). Two-way interactions were included for the fixed factors, and the three-way interaction was included in the final model if significant. Due to imbalances in sample sizes, type III sums of squares are reported, and degrees of freedom were calculated using the Kenward-Roger method (Kenward \& Roger, 1997). When main effects and interactions were significant, Tukey-adjusted least-square mean comparisons were made.

To examine trends across species, mean species responses to the herbivory and drought treatments were analyzed using the approach 
TABLE 2 Mortality effects across species throughout the experiment

\begin{tabular}{lccll} 
Species & N & Drought & Herbivory & Drought $\times$ Herbivory \\
\hline Acacia koa & 268 & 1.00 & 0.31 & 0.01 \\
Argemone glauca & 183 & 0.43 & 0.04 & 0.11 \\
\hline Bidens torta & 121 & $15.94^{* *}$ & 0.64 & 0.08 \\
\hline Dodonaea viscosa & 203 & 0.01 & 0.01 & 0.01 \\
\hline Eragrostis grandis & 209 & 0.01 & 0.01 & 0.01 \\
\hline Jacquemontia sandwicensis & 203 & 0.01 & 0.01 & 0.01 \\
\hline Metrosideros polymorpha & 176 & $26.52^{* * *}$ & 0.01 & 1.19 \\
\hline Myrsine lessertiana & 135 & 0.01 & 0 & 0.01 \\
\hline Nestegis sandwicensis & 184 & 0.01 & 0 & 0 \\
\hline Sophora chrysophylla & 170 & 0.08 & 0.01 & 0.46 \\
\hline
\end{tabular}

Note: Tests of drought, herbivory, and their interaction are reported as Wald chi-square joint tests, and significant effects are shown as follows: ${ }^{* * *}, p<.0001$; $^{* *}, p<.01$; and ${ }^{*}, p<.05$. of meta-analysis with the "metafor" package in $\mathrm{R}$ version 3.5.1 (Viechtbauer, 2014). The use of meta-analysis allows us to examine seedling responses to herbivory and drought across species using effect sizes, which are generally more informative than comparing test significance, particularly when species vary in sample sizes (Nakagawa \& Cuthill, 2007), and the use of meta-analysis to synthesize results across sites or species within studies is not uncommon (Agrawal et al., 2005; Fajardo \& Siefert, 2018; Gurevitch, 2013). Log-response ratios for total biomass were calculated from means, standard deviations, and sample sizes for the control and treatment groups of each species as follows: $\ln \left(M_{S} / M_{C}\right)$, where $M_{S}$ is the mean biomass of stressed groups (herbivory, pulse drought, 70FC press drought, pulse drought + herbivory, and 70FC press drought + herbivory), and $\mathrm{M}_{\mathrm{C}}$ is the mean biomass of control groups, so that positive response ratios indicate over-compensation (greater growth in stressed than control groups) and negative response ratios indicate under-compensation (lower growth in stressed than control groups). Mixed-model analyses using the rma.mv function tested for variation in tolerance (a) to the three types of stressors (herbivory, pulse drought, 70FC press drought); (b) to single versus multiple stressors; (c) over time (early versus late harvest); (d) between woody versus. herbaceous species; and (e) among the 10 focal species.

Because species varied significantly in tolerance to herbivory and drought (see Results), we ran correlation analyses to test whether species traits (mean seed mass or root/shoot biomass ratio quantified at the pre-harvest) are potential mechanisms underlying variation in stress tolerance (log-response ratios).

\section{3 | RESULTS}

Mortality rates were low in most species, typically below $10 \%$ in treatment and controls (Table S1). Exceptions include B. torta and M. polymorpha, which had significantly greater mortality for seedlings in drought (44\%-52\% and 65\%-95\%, respectively) than control watering conditions (5\% and 14\%, respectively; Table 2, Table S1). Herbivory did not influence mortality in any species, nor did we detect interactive effects between drought and herbivory on mortality (Table 2).

Drought altered biomass allocation, detected at the "pre-harvest" in only four species: A. koa, B. torta, E. grandis, and N. sandwicensis (Table 3, Figure 1). In these four species, root/shoot ratios were higher in plants in the drought groups compared with that of control plants.

From the early and late harvest data, we found that both herbivory and drought significantly reduced total plant biomass in most species (Table 4, Figure 2, Figures S1-S3). Only A. glauca fully tolerated herbivory, and full drought tolerance was only detected in M. polymorpha, with similar total biomass in drought and control groups for those seedlings that survived drought (Table 4). Not surprisingly, plants grew between harvest times, leading to significant main effects of harvest on total biomass in all species but M. polymorpha (Table 4). Overall, there is limited evidence that drought and herbivory have non-additive effects on seedling biomass (Table 4), with only one marginally significant two-way interaction in $D$. viscosa (herbivory*drought, $p=.0734$ ) and one significant three-way interaction detected in B. torta (herbivory*drought*harvest, $p=.0158$ ). Specifically, in $D$. viscosa, negative effects of herbivory on total biomass were stronger for plants subjected to the 4-week pulse drought than for plants subjected to the 70FC press drought (Figure 2). Similarly, in B. torta, herbivory suppressed biomass more in pulse drought than 70FC drought, but only in the early harvest, leading to a significant three-way interaction (Table 4, Figure S1).

Significant two-way interactions between harvest time and drought or harvest time and herbivory reveal that tolerance shifts during early seedling development (Table 4). For some species, tolerance increased over time, resulting in greater negative treatment effects at the early than late harvest (Figure S1). For A. koa, this meant that by the late harvest, seedlings had acclimated to the drought treatments, showing no evidence of drought suppressing growth (Figure S1). For B. torta and J. sandwicensis, herbivory reduced total plant biomass at the early harvest, but by the late harvest, the damaged seedlings had recovered to achieve similar sizes as the control 
TABLE 3 Effects of drought on root/shoot biomass ratio assessed from plants harvested on the day before the herbivory treatment ("pre-harvest")

\begin{tabular}{|lll|}
\hline Species & N & Root/Shoot ratio \\
\hline Acacia koa & 35 & $3.92^{*}$ \\
\hline Argemone glauca & 33 & 1.49 \\
\hline Bidens torta & 12 & $4.44^{*}$ \\
\hline Dodonaea viscosa & 44 & 1.54 \\
\hline Eragrostis grandis & 41 & $6.52^{* *}$ \\
\hline Jacquemontia sandwicensis & 38 & 0.25 \\
\hline Metrosideros polymorpha & 19 & 0.77 \\
\hline Myrsine lessertiana & 24 & 1.21 \\
\hline Nestegis sandwicensis & 28 & $7.72^{* *}$ \\
\hline Sophora chrysophylla & 27 & 1.77 \\
\hline
\end{tabular}

Note: Reported are type III F-tests, and significant effects are shown as follows: ${ }^{* *}, p<.01 ;$ and ${ }^{*}, p<.05$.

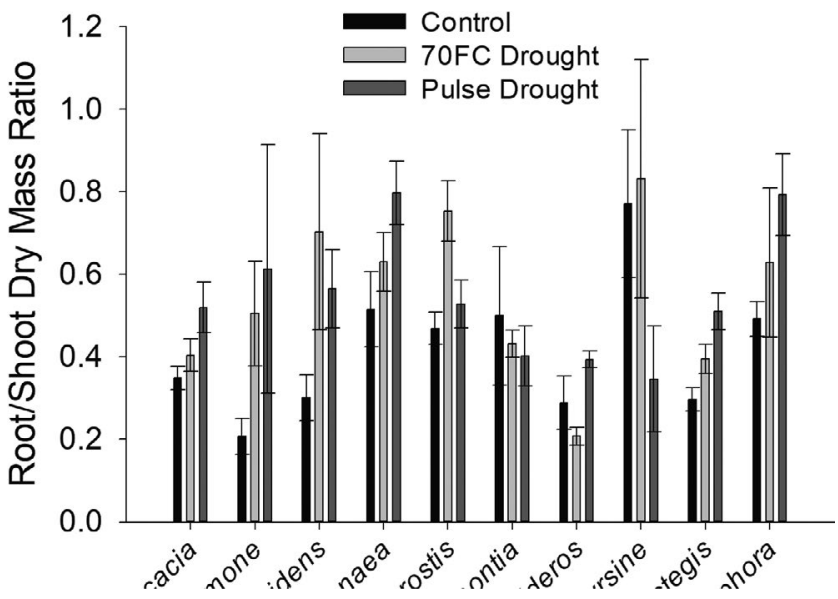

FIGURE 1 Root/shoot ratio calculated from dry mass harvested on the final day of the pulse drought, before herbivory treatments were applied. Drought was imposed as a press-drought treatment in which plants received measured water to maintain a $70 \%$ field capacity soil water content throughout the experimental period ("70FC") or as a pulse drought during which plants received no water for a four-week period ("Pulse Drought"). Seedlings were harvested 2 ("Early Harvest") or 5 ("Late Harvest") weeks following the herbivory treatment. Bars are means \pm 1 standard error $(n=4-12)$

plants (Figure S1). In contrast, some species showed stronger negative effects of drought and herbivory in the late compared with early harvest (Table 4, Figure S2), revealing weakening tolerance over time. For E. grandis and S. chrysophylla, drought effects increased over time (particularly for seedlings in the 70FC press drought), while $M$. polymorpha and $M$. lessertiana revealed increasingly negative effects of the herbivory treatment over time (Figure S2). Finally, for some species (A. glauca and N. sandwicensis), tolerance was relatively stable over time, as indicated by the lack of significant interactions between harvest time and either drought or herbivory (Table 4, Figure S3).
Synthesizing species-level responses to herbivory and drought, we detected that overall, seedlings tolerated a single stressor (pulse drought, press drought, or herbivory) significantly better than they tolerated simultaneous herbivory and drought $\left(Q_{M}=112.30, d f=1, p<.0001 ;\right.$ Figure 3). Moreover, although tolerance increased significantly over time overall, revealing compensation for stress between the early and late harvests $\left(Q_{M}=7.21, d f=1, p=.0073\right)$, compensation varied among the different stress treatments, resulting in a significant interaction between stress and time using log-likelihood model comparison $\left(\chi^{2}=16.24, d f=4, p=.0027\right)$. Species tended to recover from pulse-drought treatments (alone or combined with herbivory) better than the ongoing 70FC press drought, which was maintained throughout the experimental period (Figure 3). Significant variation in seedling stress tolerance was detected among focal species $\left(\mathrm{Q}_{\mathrm{M}}=104.83, d f=9, p<.0001\right)$, ranging across species from $70 \%$ to $30 \%$ reduction in growth for stressed compared with control seedlings (Figure S4). This species variation did not reflect consistent differences between woody versus herbaceous species $\left(\mathrm{Q}_{\mathrm{M}}=1.29, \mathrm{df}=1, p=.2558\right)$.

We detected only a few marginally significant correlations between seed mass or the post-drought root/shoot ratio and seedling tolerance at the species level (Table S2). Herbivory tolerance at the early harvest was marginally greater in small-seeded species ( $r=0.616, p=.0578$ ), although this relationship was largely driven by the very low tolerance of the large-seeded $N$. sandwicensis (Figure $4 \mathrm{a}$ ) as analysis run after removing $\mathrm{N}$. sandwicensis detected no correlation between seed size and herbivory tolerance $(r=0.406$, $p=.2777)$. Consistent with predictions, species with a greater root/ shoot ratio tended to demonstrate greater short-term tolerance to the 70FC press drought ( $r=0.595, p=.0697$, Figure $4 b)$.

\section{4 | DISCUSSION}

In contrast to our prediction, the effects of simulated drought and herbivory on Hawaiian seedling performance were largely additive. Non-additive effects occur when one stressor alters the response of plants to the second stressor, usually by magnifying the combined effect beyond what would be predicted from summing the effects of each stress alone (Bernardo et al., 2019). Such synergistic effects can make it difficult to predict plant resilience under simultaneous stressors from studies examining plant responses to individual stressors. We had predicted that drought would constrain plant tolerance to subsequent herbivory, leading to non-additivity and synergistic effects of herbivory and drought on seedling survival and growth, given the widespread evidence that drought magnifies the effects of herbivory on plant fitness (Anderegg et al., 2015; Jamieson et al., 2012), via induction of a shared signaling network that mediates plant responses (Atkinson \& Urwin, 2012; Nguyen et al., 2016) and trade-offs in allocation of stored carbohydrates (Myers \& Kitajima, 2007; O'Brien et al., 2014). However, while seedlings experiencing combined drought and herbivory grew significantly less 
TAB LE 4 Treatment effects of drought and herbivory on total dry biomass ( $\mathrm{g}$ ) from early (2 weeks) and late (5 weeks) harvests across species

\begin{tabular}{|c|c|c|c|c|c|c|c|c|}
\hline Species & $N$ & Drought & Herbivory & Harvest & $\begin{array}{l}\text { Drought } \times \\
\text { Herbivory }\end{array}$ & $\begin{array}{l}\text { Drought } \times \\
\text { Harvest }\end{array}$ & $\begin{array}{l}\text { Herbivory } \times \\
\text { Harvest }\end{array}$ & 3-way int \\
\hline Acacia koa & 203 & $13.28^{* * *}$ & $33.72 * * *$ & $29.29^{* * *}$ & 2.22 & 3.0 & 1.01 & \\
\hline Bidens torta & 52 & $24.61^{* * *}$ & $8.11^{* *}$ & $20.25^{* * *}$ & 1.45 & 0.45 & $5.2^{*}$ & $4.51 *$ \\
\hline Dodonaea viscosa & 155 & $30.03^{* * *}$ & $46.41^{* * *}$ & $84.49^{* * *}$ & 2.66 & 1.42 & 0.06 & \\
\hline Jacquemontia sandwicensis & 160 & $14.58^{* * *}$ & $39.42^{* * *}$ & $108.42^{* * *}$ & 0.1 & 2.1 & $4.53 *$ & \\
\hline Metrosideros polymorpha & 48 & 2.99 & $13.1^{* * *}$ & 0.73 & 0.31 & 0.63 & $10.49^{* *}$ & \\
\hline Myrsine lessertiana & 93 & $16.93^{* * *}$ & $62.2^{* * *}$ & $75.45^{* * *}$ & 2.17 & 1.73 & 3.23 & \\
\hline Nestegis sandwicensis & 139 & $16.30^{* * *}$ & $25.39^{* * *}$ & $14.16^{* * *}$ & 0.32 & 0.03 & 1.03 & \\
\hline Sophora chrysophylla & 124 & $5.06^{* *}$ & $22.09^{* * *}$ & $26.13^{* * *}$ & 1.57 & $4.34^{*}$ & 0.07 & \\
\hline
\end{tabular}

Note: Reported are type III F-tests, and significant effects are shown as follows: ${ }^{* *}, p<.0001 ;{ }^{* *}, p<.01$; and ${ }^{*}, p<.05$. Three-way interactions were removed from models when not significant.

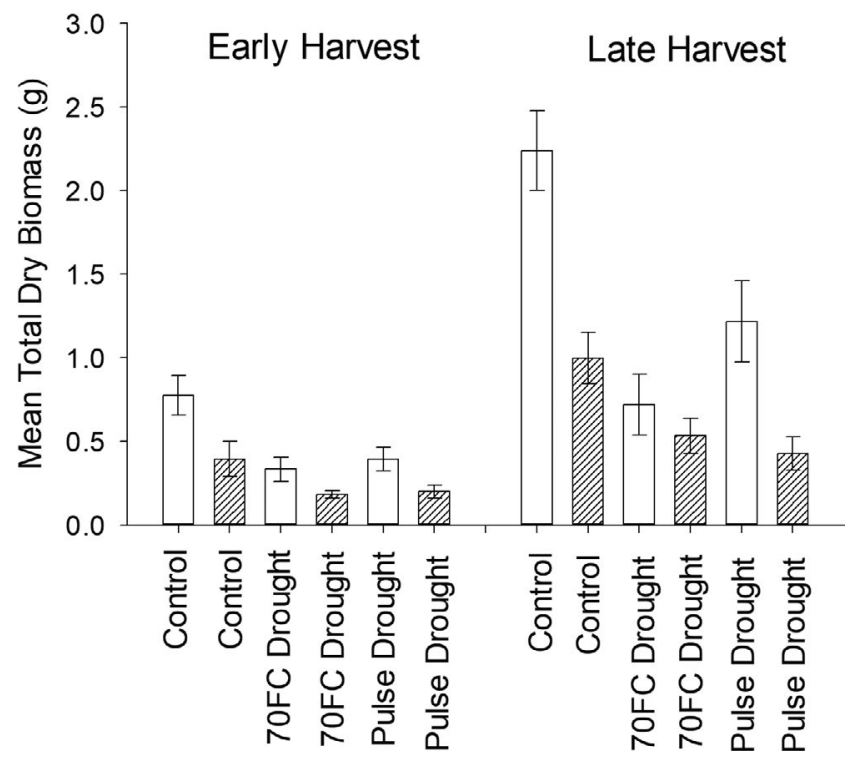

FIGURE 2 Mean total dry biomass for Dodonaea viscosa, demonstrating marginally significant non-additivity in effects of simulated herbivory (hatched bars) and simulated drought treatments on seedling growth. Drought was imposed as a pressdrought treatment in which plants received measured water to maintain a $70 \%$ field capacity soil water content throughout the experimental period ("70FC") or as a pulse drought during which plants received no water for a four-week period ("Pulse Drought"). Seedlings were harvested 2 ("Early Harvest") or 5 ("Late Harvest") weeks following the herbivory treatment. Bars are means \pm 1 standard error $(n=4-12)$

than seedlings experiencing only drought or herbivory, the combined effects were largely additive. Perhaps our results differ from most previous studies investigating interactions between herbivory and drought because most of those studies detected non-additivity mediated through resistance traits, such as secondary chemicals (Gaylord et al., 2013; Netherer et al., 2015). Our focus on tolerance metrics (survival and compensatory growth) highlights how drought

\section{EARLY HARVEST}

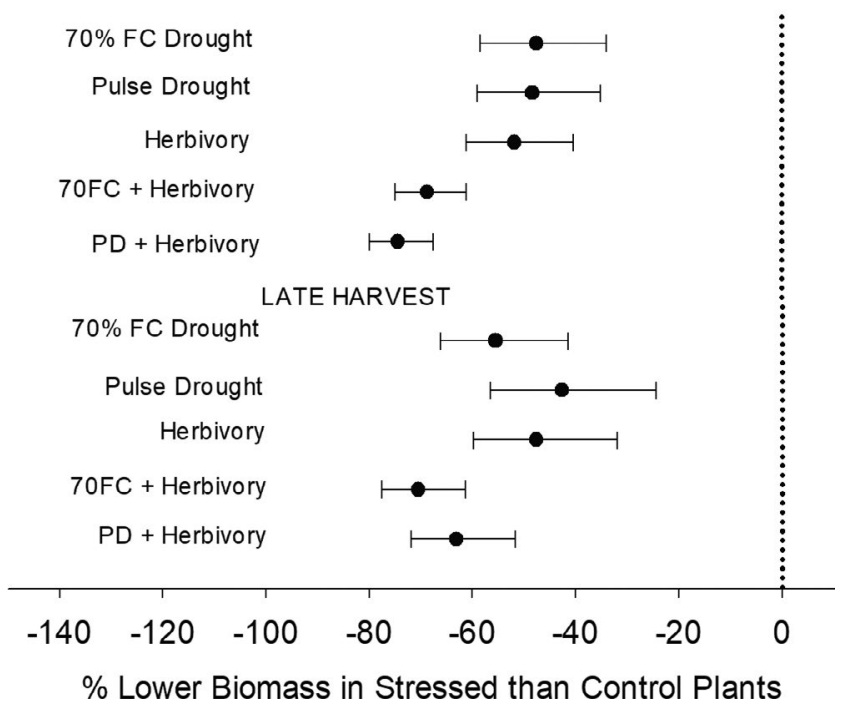

FIGURE 3 Percent reduction in total biomass of stressed versus. control plants subjected to individual ( $70 \%$ FC press drought, pulse drought, and herbivory) and combined (70\% FC or pulse drought plus herbivory) stress treatments and harvested 2 weeks ("Early") or 5 weeks ("Late") following herbivory treatments. Calculated from log-response ratios, with bias-corrected $95 \%$ confidence intervals. Sample sizes are 9-10 species

may alter plant-herbivore interactions differently via resistance versus tolerance defense mechanisms.

For the few species in which non-additivity was detected, we found that the more extreme pulse drought reduced seedling herbivory tolerance compared with seedlings exposed to the 70FC pressdrought or control water conditions. That the intensity of drought matters for understanding non-additives in biotic $\times$ abiotic stress tolerance underscores the importance of implementing more complex drought stress treatments that coincide with projected shifts in precipitation frequency, duration, and intensity (Beier et al., 2012; Hoover, Duniway, \& Belnap, 2015; Smith, 2011). For example, in 


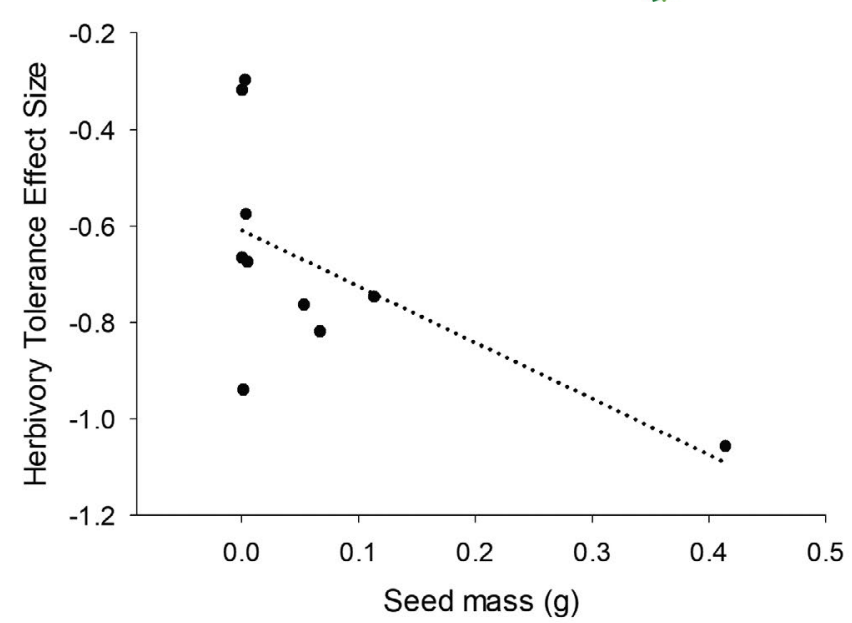

As predicted, we observed significant variation among species in their stress tolerance, although no species demonstrated full tolerance to either herbivory or drought stress within the experimental timeframe. Considering the phylogenetic diversity represented (10 species from 10 plant families) and the range in growth form and habitat types, variation across species is not surprising. Consistent with other studies (Denton et al., 2018; Eziz et al., 2017; Larson \& Funk, 2016; Lucas et al., 2013), seedling drought induced a shift in root/shoot ratio in some species, and drought tolerance was positively linked to root/shoot ratio across species. In the four species demonstrating phenotypic plasticity, root/shoot ratios were higher in plants in the drought groups compared with that of control plants, as predicted by adaptive plasticity of organs to maximize uptake of limited resources (Denton et al., 2018; Larson \& Funk, 2016; Lucas et al., 2013). Greater investment in roots enhances drought tolerance through greater access to water as well as greater storage,

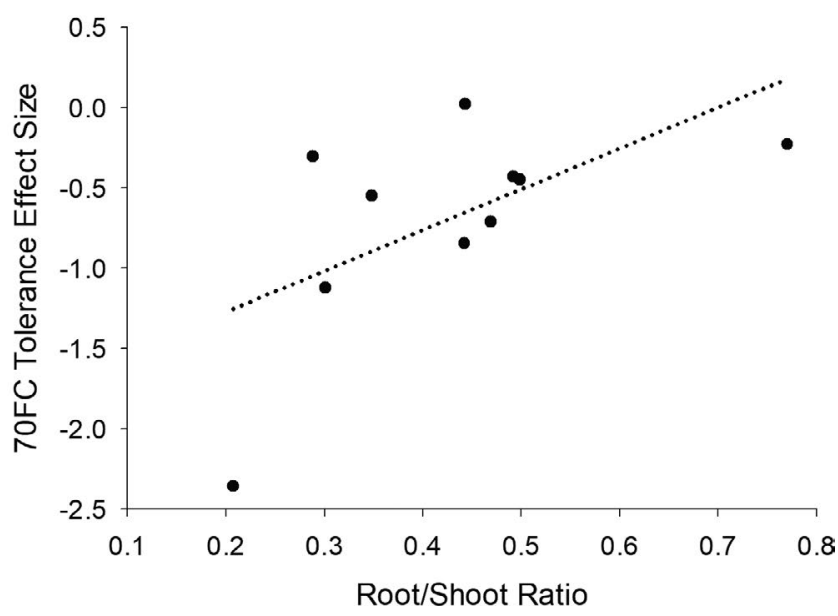

FIGURE 4 Pearson correlations with best-fit line between tolerance and species mean traits at the early harvest, in which tolerance is quantified as log-response ratio effect sizes: $L R R=\ln \left(M_{S} / M_{C}\right)$, where $M_{S}$ is the mean biomass of stressed groups (herbivory, pulse drought, 70FC press drought, pulse drought + herbivory, and 70FC press drought + herbivory), and $M_{C}$ is the mean biomass of control groups. Species is the unit of replication, and sample sizes are 9-10 species. Marginally significant correlations were detected between seed mass and herbivory tolerance (a) and root/shoot ratio and $70 \% \mathrm{FC}$ pressdrought tolerance (b)

a previous study on one of the same focal species examined here, Metrosideros polymorpha seedlings exposed to a range of simulated drought treatments that varied in intensity and duration demonstrated complex responses in plasticity of photosynthetic parameters to the drought treatments (Westerband et al., 2019). Specifically, although M. polymorpha mortality was greatest under the longest drought treatment, growth under drought was maximized in surviving seedlings with higher chlorophyll content and greater stomatal conductance (Westerband et al., 2019). Complex watering treatments are necessary to characterize plant responses to more realistic climate change scenarios and are particularly needed for tests of simultaneous multiple stressors such as drought and herbivory. can function in osmoregulation to maintain water uptake (O'Brien et al., 2014).

Seed mass was not found to be linked to drought tolerance across species, but did relate to herbivory tolerance. In contrast to our prediction, small-seeded species tended to have greater herbivory tolerance than large-seeded species, although this relationship is likely driven by a single outlier, the very low tolerance of the large-seeded N. sandwicensis. The presumed function of seed mass for seedling tolerance is in the provision of stored non-structural carbohydrates (NSC) for re-growth or osmoregulation. However, seed mass is not always a good predictor of seedling tolerance (Lucas et al., 2013; Myers \& Kitajima, 2007), because of potential mismatches between seed mass and NSC content and because of the high relative growth rates of small-seeded species (O'Brien, Philipson, Tay, \& Hector, 2013). Because we did not examine physiological responses to the experimental treatments, it remains largely unclear what drives the observed variation in drought and herbivory tolerance across species. Previous work on Hawaiian seedlings have revealed chlorophyll content, stomatal conductance, and non-photochemical quenching to function in drought and herbivory tolerance (Barton, 2016; Westerband et al., 2019), and future work is needed to determine plant ecophysiological responses to the combined stressors (Mundim \& Pringle, 2018).

Despite variation across species, tolerance to herbivory and drought alone and in combination was generally quite low in this study. Considering the projected increases in aridity (Chu et al., 2010; Cook et al., 2014; Frazier \& Giambelluca, 2017; Timm et al., 2015) for the Hawaiian Islands, as well as the high abundances of invasive herbivores that target seedlings (Joe \& Daehler, 2008; Shiels, Ennis, et al., 2014; Shiels, Pitt, et al., 2014), low seedling tolerance among the native plants to these stressors could limit future population regeneration. Particularly worrisome are the very high mortality rates of Hawaii's most abundant and widespread keystone tree species, M. polymorpha, to simulated drought, and the trend for some species such as $N$. sandwicensis to have weaker tolerance to herbivory and drought over time. 
These patterns corroborate earlier studies showing similarly high mortality of $M$. polymorpha to extreme experimental drought (Westerband et al., 2019), and increasingly weaker tolerance to simulated herbivory in several native Campanulaceae species (Barton, 2016). Future studies considering population variation in seedling drought tolerance will provide additional insights into whether these results apply throughout the species' distributions, especially for widespread species such as M. polymorpha, which demonstrate local adaptation in seedling drought tolerance on Oahu (Barton, Jones, Edwards, Shiels, \& Knight, 2020). Conservation of this unique endemic flora may become increasingly threatened as drought increases and invasive herbivory continues, highlighting the continued need for intensive management to foster native seedling recruitment. Moreover, these results likely extend to other tropical island systems where climate change and invasive herbivory are implicated in native plant declines (Caujape-Castells et al., 2010; Harter et al., 2015) and where similar experimental studies are needed to determine plant responses to their combined effects in order to develop effective conservation plans.

\section{ACKNOWLEDGMENTS}

The authors thank A. Coley, N. Nguyen, V. Rogers-Phillips, L. Watanabe, and J. Quayle for assistance with the experiment. Funding was provided by the USDA APHIS Wildlife Research Program.

\section{DATA AVAILABILITY STATEMENT}

Data are available from the Dryad Digital Repository: https://doi. org/10.5061/dryad.rv15dv45j (Barton \& Shiels, 2020).

\section{ORCID}

Kasey E. Barton (iD https://orcid.org/0000-0002-4549-4150

Aaron B. Shiels iD https://orcid.org/0000-0002-6774-4560

\section{REFERENCES}

Agrawal, A. A., Kotanen, P. M., Mitchell, C. E., Power, A. G., Godsoe, W., \& Klironomos, J. (2005). Enemy release? An experiment with congeneric plant pairs and diverse above- and belowground enemies. Ecology, 86, 2979-2989. https://doi.org/10.1890/05-0219

Allen, K., Dupuy, J. M., Gei, M. G., Hulshof, C., Medvigy, D., Pizano, C., ... Powers, J. S. (2017). Will seasonally dry tropical forests be sensitive or resistant to future changes in rainfall regimes? Environmental Research Letters, 12, 15. https://doi.org/10.1088/1748-9326/ aa5968

Anderegg, W. R. L., Hicke, J. A., Fisher, R. A., Allen, C. D., Aukema, J., Bentz, B., ... Zeppel, M. (2015). Tree mortality from drought, insects, and their interactions in a changing climate. New Phytologist, 208, 674-683.

Armstrong, D. P., \& Westoby, M. (1993). Seedlings from large seeds tolerate defoliation better - a test using phylogenetically independent contrasts. Ecology, 74, 1092-1100.

Aslan, C. E., Shiels, A. B., Haines, W., \& Liang, C. T. (2019). Non-native insects dominate daytime pollination in a high-elevation Hawaiian dryland ecosystem. American Journal of Botany, 106, 313-324. https:// doi.org/10.1002/ajb2.1233
Aslan, C. E., Zavaleta, E. S., Tershy, B., Croll, D., \& Robichaux, R. H. (2014). Imperfect replacement of native species by non-native species as pollinators of endemic Hawaiian plants. Conservation Biology, 28, 478-488. https://doi.org/10.1111/cobi.12193

Atkinson, N. J., \& Urwin, P. E. (2012). The interaction of plant biotic and abiotic stresses: From genes to the field. Journal of Experimental Botany, 63, 3523-3543. https://doi.org/10.1093/jxb/ers100

Avramova, Z. (2019). Defence-related priming and responses to recurring drought: Two manifestations of plant transcriptional memory mediated by the ABA and JA signalling pathways. Plant Cell and Environment, 42, 983-997. https://doi.org/10.1111/pce.13458

Baldwin, P. H. (1947). Foods of the Hawaiian goose. The Condor, 49, 108120. https://doi.org/10.2307/1364358

Ball, B. A., Hunter, M. D., Kominoski, J. S., Swan, C. M., \& Bradford, M. A. (2008). Consequences of non-random species loss for decomposition dynamics: Experimental evidence for additive and non-additive effects. Journal of Ecology, 96, 303-313. https://doi. org/10.1111/j.1365-2745.2007.01346.x

Baltzer, J. L., \& Davies, S. J. (2012). Rainfall seasonality and pest pressure as determinants of tropical tree species' distributions. Ecology and Evolution, 2, 2682-2694. https://doi.org/10.1002/ece3.383

Barton, K. E. (2013). Ontogenetic patterns in the mechanisms of tolerance to herbivory in Plantago. Annals of Botany, 112, 711-720. https:// doi.org/10.1093/aob/mct083

Barton, K. E. (2016). Low tolerance to simulated herbivory in Hawaiian seedlings despite induced changes in photosynthesis and biomass allocation. Annals of Botany, 117, 1053-1062. https://doi.org/10.1093/ aob/mcw021

Barton, K. E., \& Hanley, M. E. (2013). Seedling-herbivore interactions: Insights into plant defence and regeneration patterns. Annals of Botany, 112, 643-650. https://doi.org/10.1093/aob/mct139

Barton, K. E., Jones, C., Edwards, K. F., Shiels, A. B., \& Knight, T. (2020). Local adaptation constrains drought tolerance in a tropical foundation tree. Journal of Ecology, 108(4), 1540-1552. https://doi. org/10.1111/1365-2745.13354

Barton, K. E., \& Shiels, A. B. (2020). Data from: Additive and non-additive responses of seedlings to simulated herbivory and drought. Dryad Digital Repository, https://doi.org/10.5061/dryad.rv15d v45j

Barton, K. E., Valkama, E., Vehvilainen, H., Ruohomaki, K., Knight, T. M., $\&$ Koricheva, J. (2015). Additive and non-additive effects of birch genotypic diversity on arthropod herbivory in a long-term field experiment. Oikos, 124, 697-706. https://doi.org/10.1111/oik.01663

Beier, C., Beierkuhnlein, C., Wohlgemuth, T., Penuelas, J., Emmett, B., Korner, C., ... Hansen, K. (2012). Precipitation manipulation experiments - challenges and recommendations for the future. Ecology Letters, 15, 899-911. https://doi. $\operatorname{org} / 10.1111 /$ j.1461-0248.2012.01793.x

Bernardo, H. L., Goad, R., Vitt, P., \& Knight, T. M. (2019). Nonadditive effects among threats on rare plant species. Conservation Biology. https://doi.org/10.1111/cobi.13441

Black, J., Hunter, J., Woog, F., Marshall, A. P., \& Bowler, J. (1998). Foraging behavior and energetics of the Hawaiian Goose Branta sandvicensis. Wildfowl, 45, 65-109.

Bonal, D., Burban, B., Stahl, C., Wagner, F., \& Herault, B. (2016). The response of tropical rainforests to drought-lessons from recent research and future prospects. Annals of Forest Science, 73, 27-44. https://doi.org/10.1007/s13595-015-0522-5

Bossdorf, O., Schroder, S., Prati, D., \& Auge, H. (2004). Palatability and tolerance to simulated herbivory in native and introduced populations of Alliaria petiolata (Brassicaceae). American Journal of Botany, 91, 856-862.

Bowen, L., \& VanVuren, D. (1997). Insular endemic plants lack defenses against herbivores. Conservation Biology, 11, 1249-1254. https://doi. org/10.1046/j.1523-1739.1997.96368.x 
Caujape-Castells, J., Tye, A., Crawford, D. J., Santos-Guerra, A., Sakai, A., Beaver, K., ... Kueffer, C. (2010). Conservation of oceanic island floras: Present and future global challenges. Perspectives in Plant Ecology Evolution and Systematics, 12, 107-129. https://doi.org/10.1016/j. ppees.2009.10.001

Christmas, M. J., Breed, M. F., \& Lowe, A. J. (2016). Constraints to and conservation implications for climate change adaptation in plants. Conservation Genetics, 17, 305-320. https://doi.org/10.1007/s1059 2-015-0782-5

Chu, P. S., Chen, Y. R., \& Schroeder, T. A. (2010). Changes in precipitation extremes in the hawaiian islands in a warming climate. Journal of Climate, 23, 4881-4900. https://doi.org/10.1175/2010JCLI34 84.1

Cole, R. J., Litton, C. M., Koontz, M. J., \& Loh, R. K. (2012). Vegetation recovery 16 years after feral pig removal from a Wet Hawaiian Forest. Biotropica, 44, 463-471. https://doi. org/10.1111/j.1744-7429.2011.00841.x

Comita, L., \& Engelbrecht, B. M. J. (2014). Drought as a driver of tropical tree species regeneration dynamics and distribution patterns. In D. Coomes, D. Burslem \& W. Simonson (Eds.), Forests and global change (pp. 261-308). Cambridge, UK: Cambridge University Press.

Cook, B. I., Smerdon, J. E., Seager, R., \& Coats, S. (2014). Global warming and 21st century drying. Climate Dynamics, 43, 2607-2627. https:// doi.org/10.1007/s00382-014-2075-y

Davidson, C. B., Gottschalk, K. W., \& Johnson, J. E. (1999). Tree mortality following defoliation by the European gypsy moth (Lymantria dispar L.) in the United States: A review. Forest Science, 45, 74-84.

Denton, E. M., Smith, B. S., Hamerlynck, E. P., \& Sheley, R. L. (2018). Seedling defoliation and drought stress: Variation in intensity and frequency affect performance and survival. Rangeland Ecology \& Management, 71, 25-34.https://doi.org/10.1016/j.rama.2017.06.014

Drake, D. R. (1992). Seed dispersal of Metrosideros polymorpha (Myrtaceae) - a pioneer tree of Hawaiian lava flows. American Journal of Botany, 79, 1224-1228. https://doi.org/10.1002/j.1537-2197.1992.tb137 24. $x$

Dyer, L. A., Carson, W. P., \& Leigh, E. G. J. (2012). Insect outbreaks in tropical forests: patterns, mechanisms, and consequences. In P. Barbosa, D. K. Letourneau \& A. A. Agrawal (Eds.), Insect outbreaks revisited (pp. 219-245). Chichester, UK \& Hoboken, NJ: Blackwell Publishing Ltd.

Engelbrecht, B. M. J., \& Kursar, T. A. (2003). Comparative drought-resistance of seedlings of 28 species of co-occurring tropical woody plants. Oecologia, 136, 383-393. https://doi.org/10.1007/s0044 2-003-1290-8

Eziz, A., Yan, Z. B., Tian, D., Han, W. X., Tang, Z. Y., \& Fang, J. Y. (2017). Drought effect on plant biomass allocation: A meta-analysis. Ecology and Evolution, 7, 11002-11010. https://doi.org/10.1002/ece3.3630

Fajardo, A., \& Siefert, A. (2018). Intraspecific trait variation and the leaf economics spectrum across resource gradients and levels of organization. Ecology, 99, 1024-1030. https://doi.org/10.1002/ecy.2194

Fang, X. W., Yuan, J. L., Wang, G., \& Zhao, Z. G. (2006). Fruit production of shrub, Caragana korshinskii, following above-ground partial shoot removal: Mechanisms underlying compensation. Plant Ecology, 187, 213-225.

Fornoni, J. (2011). Ecological and evolutionary implications of plant tolerance to herbivory. Functional Ecology, 25, 399-407. https://doi. org/10.1111/j.1365-2435.2010.01805.x

Frazier, A. G., \& Giambelluca, T. W. (2017). Spatial trend analysis of Hawaiian rainfall from 1920 to 2012. International Journal of Climatology, 37, 2522-2531. https://doi.org/10.1002/joc.4862

Freeman, R. S., Brody, A. K., \& Neefus, C. D. (2003). Flowering phenology and compensation for herbivory in Ipomopsis aggregata. Oecologia, 136, 394-401. https://doi.org/10.1007/s00442-003-1276-6

Funk, J. L., \& Throop, H. L. (2010). Enemy release and plant invasion: Patterns of defensive traits and leaf damage in Hawaii. Oecologia, 162, 815-823. https://doi.org/10.1007/s00442-009-1497-4
Gaviria, J., Turner, B. L., \& Engelbrecht, B. M. J. (2017). Drivers of tree species distribution across a tropical rainfall gradient. Ecosphere, 8 , 16. https://doi.org/10.1002/ecs2.1712

Gaylord, M. L., Kolb, T. E., Pockman, W. T., Plaut, J. A., Yepez, E. A., Macalady, A. K., ... McDowell, N. G. (2013). Drought predisposes pinon-juniper woodlands to insect attacks and mortality. New Phytologist, 198, 567-578.

Gerhardt, K. (1996). Effects of root competition and canopy openness on survival and growth of tree seedlings in a tropical seasonal dry forest. Forest Ecology and Management, 82, 33-48. https://doi. org/10.1016/0378-1127(95)03700-4

Giambelluca, T. W., Chen, Q., Frazier, A. G., Price, J. P., Chen, L.-L., Chu, P.-S., ... Delparte, D. M. (2013). Online rainfall atlas of Hawaii. Bulletin of American Meteorological Society, 94, 313-316. https://doi. org/10.1175/BAMS-D-11-00228.1

Gianoli, E., \& Salgado-Luarte, C. (2017). Tolerance to herbivory and the resource availability hypothesis. Biology Letters, 13, 4. https://doi. org/10.1098/rsbl.2017.0120

Givnish, T. J., Sytsma, K. J., Smith, J. F., \& Hahn, W. J. (1994). Thornlike prickles and heterophylly in Cyanea - adaptations to extinct avian browsers on Hawai'i. Proceedings of the National Academy of Sciences of the United States of America, 91, 2810-2814. https://doi. org/10.1073/pnas.91.7.2810

Green, P. T., \& Juniper, P. A. (2004). Seed mass, seedling herbivory and the reserve effect in tropical rainforest seedlings. Functional Ecology, 18, 539-547.

Gurevitch, J. (2013). Meta-analysis of results from multisite studies. In J. Koricheva, J. Gurevitch \& K. Mengersen (Eds.), Handbook of meta-analysis in ecology and evolution (pp. 313-322). Princeton, NJ: Princeton University Press.

Harter, D. E. V., Irl, S. D. H., Seo, B., Steinbauer, M. J., Gillespie, R., Triantis, K. A., ... Beierkuhnlein, C. (2015). Impacts of global climate change on the floras of oceanic islands - Projections, implications and current knowledge. Perspectives in Plant Ecology Evolution and Systematics, 17 160-183.

Hess, S. C., Banko, P. C., Miller, L. J., \& Laniawe, L. P. (2014). Habitat and food preferences of the endangered palila (Loxioides bailleui) on Mauna Kea. Hawaii. Wilson Journal of Ornithology, 126, 728-738.

Hoan, R., Ormond, R., \& Barton, K. E. (2014). Prickly poppies can get pricklier: Ontogenetic patterns in the induction of physical defense traits. PLoS One, 9, E96796. https://doi.org/10.1371/journal.pone.0096796

Hoover, D. L., Duniway, M. C., \& Belnap, J. (2015). Pulse-drought atop press-drought: Unexpected plant responses and implications for dryland ecosystems. Oecologia, 179, 1211-1221. https://doi. org/10.1007/s00442-015-3414-3

Jamieson, M. A., Trowbridge, A. M., Raffa, K. F., \& Lindroth, R. L. (2012). Consequences of climate warming and altered precipitation patterns for plant-insect and multitrophic interactions. Plant Physiology, 160, 1719-1727. https://doi.org/10.1104/pp.112.206524

Joe, S. M., \& Daehler, C. C. (2008). Invasive slugs as under-appreciated obstacles to rare plant restoration: Evidence from the Hawaiian Islands. Biological Invasions, 10, 245-255. https://doi.org/10.1007/ s10530-007-9126-9

Kenward, M. G., \& Roger, J. H. (1997). Small sample inference for fixed effects from restricted maximum likelihood. Biometrics, 53, 983-997. https://doi.org/10.2307/2533558

Kier, G., Kreft, H., Lee, T. M., Jetz, W., Ibisch, P. L., Nowicki, C., ... Barthlott, W. (2009). A global assessment of endemism and species richness across island and mainland regions. Proceedings of the National Academy of Sciences of the United States of America, 106 9322-9327. https://doi.org/10.1073/pnas.0810306106

Krishnan, L., Barua, D., \& Sankaran, M. (2019). Dry-forest tree species with large seeds and low stem specific density show greater survival under drought. Journal of Tropical Ecology, 35, 26-33. https://doi. org/10.1017/S0266467418000421 
Larson, J. E., \& Funk, J. L. (2016). Seedling root responses to soil moisture and the identification of a belowground trait spectrum across three growth forms. New Phytologist, 210, 827-838. https://doi. org/10.1111/nph.13829

Latzel, V., Malikova, L., \& Klimesova, J. (2011). Compensatory growth of Euphorbia peplus regenerating from a bud bank. Botany-Botanique, 89, 313-321.

Lucas, C. M., Bruna, E. M., \& Nascimento, C. M. N. (2013). Seedling co-tolerance of multiple stressors in a disturbed tropical floodplain forest. Ecosphere, 4, 20. https://doi.org/10.1890/ES12-00287.1

Lurie, M. H., Barton, K. E., \& Daehler, C. C. (2017). Pre-damage biomass allocation and not invasiveness predicts tolerance to damage in seedlings of woody species in Hawaii. Ecology, 98, 3011-3021. https://doi.org/10.1002/ecy.2031

Marod, D., Kutintara, U., Tanaka, H., \& Nakashizuka, T. (2002). The effects of drought and fire on seed and seedling dynamics in a tropical seasonal forest in Thailand. Plant Ecology, 161, 41-57.

Maron, J. L., Baer, K. C., \& Angert, A. L. (2014). Disentangling the drivers of context-dependent plant-animal interactions. Journal of Ecology, 102, 1485-1496. https://doi.org/10.1111/1365-2745.12305

Martinez-Vilalta, J., \& Lloret, F. (2016). Drought-induced vegetation shifts in terrestrial ecosystems: The key role of regeneration dynamics. Global and Planetary Change, 144, 94-108. https://doi.org/10.1016/j. gloplacha.2016.07.009

Massad, T. J. (2013). Ontogenetic differences of herbivory on woody and herbaceous plants: A meta-analysis demonstrating unique effects of herbivory on the young and the old, the slow and the fast. Oecologia, 172, 1-10. https://doi.org/10.1007/s00442-012-2470-1

McDowell, N., Allen, C. D., Anderson-Teixeira, K., Brando, P., Brienen, R., Chambers, J., ... Xu, X. T. (2018). Drivers and mechanisms of tree mortality in moist tropical forests. New Phytologist, 219, 851-869. https:// doi.org/10.1111/nph.15027

Moles, A. T., \& Westoby, M. (2004). Seedling survival and seed size: A synthesis of the literature. Journal of Ecology, 92, 372-383. https:// doi.org/10.1111/j.0022-0477.2004.00884.x

Mundim, F. M., \& Pringle, E. G. (2018). Whole-plant metabolic allocation under water stress. Frontiers in Plant Science, 9, 12. https://doi. org/10.3389/fpls.2018.00852

Murphy, M. J., Inman-Narahari, F., Ostertag, R., \& Litton, C. M. (2014). Invasive feral pigs impact native tree ferns and woody seedlings in Hawaiian forest. Biological Invasions, 16, 63-71. https://doi. org/10.1007/s10530-013-0503-2

Myers, J. A., \& Kitajima, K. (2007). Carbohydrate storage enhances seedling shade and stress tolerance in a neotropical forest. Journal of Ecology, 95, 383-395. https://doi.org/10.1111/j.1365-2745.2006.01207.x

Nakagawa, S., \& Cuthill, I. C. (2007). Effect size, confidence interval and statistical significance: A practical guide for biologists. Biological Reviews, 82, 591-605.

Netherer, S., Matthews, B., Katzensteiner, K., Blackwell, E., Henschke, P., Hietz, P., ... Schopf, A. (2015). Do water-limiting conditions predispose Norway spruce to bark beetle attack? New Phytologist, 205, 1128-1141. https://doi.org/10.1111/nph.13166

Nguyen, D., Rieu, I., Mariani, C., \& van Dam, N. M. (2016). How plants handle multiple stresses: Hormonal interactions underlying responses to abiotic stress and insect herbivory. Plant Molecular Biology, 91, 727740. https://doi.org/10.1007/s11103-016-0481-8

O'Brien, M. J., Leuzinger, S., Philipson, C. D., Tay, J., \& Hector, A. (2014). Drought survival of tropical tree seedlings enhanced by non-structural carbohydrate levels. Nature Climate Change, 4, 710-714. https:// doi.org/10.1038/nclimate2281

O'Brien, M. J., Philipson, C. D., Tay, J., \& Hector, A. (2013). The influence of variable rainfall frequency on germination and early growth of shade-tolerant Dipterocarp seedlings in Borneo. PLoS One, 8, 9. https://doi.org/10.1371/journal.pone.0070287
Pender, R. J., Shiels, A. B., Bialic-Murphy, L., \& Mosher, S. M. (2013). Large-scale rodent control reduces pre- and post-dispersal seed predation of the endangered Hawaiian lobeliad, Cyanea superba subsp superba (Campanulaceae). Biological Invasions, 15, 213-223.

Peñuelas, J., Sardans, J., Llusia, J., Owen, S. M., Silva, J., \& Niinemets, U. (2010). Higher allocation to low cost chemical defenses in invasive species of Hawaii. Journal of Chemical Ecology, 36, 1255-1270. https://doi.org/10.1007/s10886-010-9862-7

Raffa, K. F., Aukema, B. H., Bentz, B. J., Carroll, A. L., Hicke, J. A., Turner, M. G., \& Romme, W. H. (2008). Cross-scale drivers of natural disturbances prone to anthropogenic amplification: The dynamics of bark beetle eruptions. BioScience, 58, 501-517. https://doi.org/10.1641/ B580607

Rasmann, S., Johnson, M. D., \& Agrawal, A. A. (2009). Induced responses to herbivory and jasmonate in three milkweed species. Journal of Chemical Ecology, 35, 1326-1334. https://doi.org/10.1007/s1088 6-009-9719-0

Sack, L. (2004). Responses of temperate woody seedlings to shade and drought: Do trade-offs limit potential niche differentiation? Oikos, 107, 110-127. https://doi.org/10.1111/j.0030-1299.2004.13184.x

Salgado-Luarte, C., \& Gianoli, E. (2017). Shade tolerance and herbivory are associated with RGR of tree species via different functional traits. Plant Biology, 19, 413-419.

Sardans, J., Llusia, J., Niinemets, U., Owen, S., \& Peñuelas, J. (2010). Foliar mono- and sesquiterpene contents in relation to leaf economic spectrum in native and alien species in O'ahu (Hawai'i). Journal of Chemical Ecology, 36, 210-226. https://doi.org/10.1007/ s10886-010-9744-z

Schwalm, C. R., Anderegg, W. R. L., Michalak, A. M., Fisher, J. B., Biondi, F., Koch, G., ... Tian, H. Q. (2017). Global patterns of drought recovery. Nature, 548, 202-205. https://doi.org/10.1038/nature23021

Shiels, A. B., \& Drake, D. R. (2011). Are introduced rats (Rattus rattus) both seed predators and dispersers in Hawai'i? Biological Invasions, 13, 883-894. https://doi.org/10.1007/s10530-010-9876-7

Shiels, A. B., Ennis, M. K., \& Shiels, L. (2014). Trait-based plant mortality and preference for native versus non-native seedlings by invasive slug and snail herbivores in Hawai'i. Biological Invasions, 16, 19291940. https://doi.org/10.1007/s10530-013-0636-3

Shiels, A. B., Pitt, W. C., Sugihara, R. T., \& Witmer, G. W. (2014). Biology and impacts of pacific island invasive species. 11. Rattus rattus, the black rat (Rodentia: Muridae). Pacific Science, 68, 145-184.

Smith, M. D. (2011). The ecological role of climate extremes: Current understanding and future prospects. Journal of Ecology, 99, 651-655. https://doi.org/10.1111/j.1365-2745.2011.01833.x

Stevens, M. T., Kruger, E. L., \& Lindroth, R. L. (2008). Variation in tolerance to herbivory is mediated by differences in biomass allocation in aspen. Functional Ecology, 22, 40-47.

Strauss, S. Y., \& Agrawal, A. A. (1999). The ecology and evolution of plant tolerance to herbivory. Trends in Ecology and Evolution, 14, 179-185. https://doi.org/10.1016/S0169-5347(98)01576-6

IPCC et al. (2014). Climate change 2014: Synthesis report. In C. W. Team, R. K. Pachauri \& L. A. Meyer (Eds.). Contribution of working groups I, II and III to the fifth assessment report of the intergovernmental panel on climate change (151 pp). Geneva, Switzerland: IPCC.

Thompson, P. L., MacLennan, M. M., \& Vinebrooke, R. D. (2018). Species interactions cause non-additive effects of multiple environmental stressors on communities. Ecosphere, 9, 13. https://doi.org/10.1002/ ecs2.2518

Thomson, V. P., Cunningham, S. A., Ball, M. C., \& Nicotra, A. B. (2003). Compensation for herbivory by Cucumis sativus through increased photosynthetic capacity and efficiency. Oecologia, 134, 167-175. https://doi.org/10.1007/s00442-002-1102-6

Tiffin, P., \& Inouye, B. D. (2000). Measuring tolerance to herbivory: Accuracy and precision of estimates made using 
natural versus imposed damage. Evolution, 54, 1024-1029. https:// doi.org/10.1111/j.0014-3820.2000.tb00101.x

Timm, O. E., Giambelluca, T. W., \& Diaz, H. F. (2015). Statistical downscaling of rainfall changes in Hawai $i$ based on the CMIP5 global model projections. Journal of Geophysical Research-Atmospheres, 120, 92-112. https://doi.org/10.1002/2014JD022059

Viechtbauer, W. R. (2014). Meta-analysis package for R.

Wallin, K. F., \& Raffa, K. F. (2001). Effects of folivory on subcortical plant defenses: Can defense theories predict interguild processes? Ecology, 82, 1387-1400. https://doi.org/10.1890/0012-9658(2001) 082[1387:EOFOSP]2.0.CO;2

Weissflog, A., Markesteijn, L., Lewis, O. T., Comita, L. S., \& Engelbrecht, B. M. J. (2018). Contrasting patterns of insect herbivory and predation pressure across a tropical rainfall gradient. Biotropica, 50, 302311. https://doi.org/10.1111/btp.12513

Westerband, A., Bialic-Murphy, L., Weisenberger, L. A., \& Barton, K. E. (2020). Intraspecific variation in seedling drought tolerance and associated traits in a critically endangered, endemic Hawaiian shrub. Plant Ecology and Diversity. https://doi.org/10.1080/17550874.2020.1730459

Westerband, A., Kagawa-Viviani, A. K., Bogner, K. K., Beilman, D. W., Knight, T. K., \& Barton, K. E. (2019). Seedling drought tolerance and functional traits vary in response to the timing of water availability in a keystone Hawaiian tree species. Plant Ecology, 220, 321-344. https://doi.org/10.1007/s11258-019-00917-0
Willaume, M., \& Pages, L. (2011). Correlated responses of root growth and sugar concentrations to various defoliation treatments and rhythmic shoot growth in oak tree seedlings (Quercus pubescens). Annals of Botany, 107, 653-662. https://doi.org/10.1093/aob/mcq270

Yoshizuka, E. M., \& Roach, D. A. (2011). Plastic growth responses to simulated herbivory. International Journal of Plant Sciences, 172, 521-529. https://doi.org/10.1086/658926

Ziegler, A. C. (2002). Hawaiian natural history, ecology, and evolution. Honolulu: University of Hawai'i Press.

\section{SUPPORTING INFORMATION}

Additional supporting information may be found online in the Supporting Information section.

How to cite this article: Barton KE, Shiels AB. Additive and non-additive responses of seedlings to simulated herbivory and drought. Biotropica. 2020;52:1217-1228. https://doi. org/10.1111/btp.12829 